\title{
Learning Styles and the Hybrid Learning: An Empirical Study about the Impact of Learning Styles on the Perception of the Hybrid Learning
}

Ariel Ora

Carleton University, Ottawa, Canada

Roland Sahatcija

Mediterranean University of Albania, Albania

Anxhela Ferhataj

European University of Tirana, Albania

Doi: $10.2478 / \mathrm{mjss}-2018-0013$

Abstract

Learning style is a crucial element in the academic life of students. It plays a fundamental role in the selection of a suitable teaching method of instruction. The aim of this research paper is the study of the perception of the hybrid learning and students' learning style. In addition, another objective of the study is to analyze the perception of the hybrid learning in accordance with the learning style. This paper employs quantitative research and the descriptive and comparative methods. The study sample consists of 89 Albanian university students. Data analysis was conducted through SPSS 20 and JASP-0.8.1.2. The statistical analyses utilized in this paper are distribution tables, crossed tabulation, student test, Pearson correlation coefficient, Bayesian Independent Samples T-Test, and One - Way ANOVA. The conclusion of the data analysis shows that most students used the visual learning style in order to study. Students have a positive perception of the hybrid learning. There exists an insignificant statistical correlation between learning styles and the perception of the hybrid learning. The area of study has an impact on the components of the hybrid learning.

Keywords: learning style, visual learning style, aural learning style, kinesthetic learning style, perception of the hybrid learning, components of the hybrid learning

\section{Introduction}

Students prefer to study subjects in different ways. Every student chooses the manner which appears to be the easiest. In order to be effective, students ought to apply the learning style with which they are most compatible. A fitting style is beneficial because it will help them achieve higher results. Simultaneously, acquainting themselves with their students' learning styles, will help professors to apply the most suitable instruction method. The hybrid learning is the most compatible method for all student types, as it combines the traditional and online learning (Collopy \& Arnold, 2009). Moreover, this instruction method is viewed as the teaching method of the future by many (Collopy \& Arnold, 2009; Dziuban, Graham, \& Picciano, 2014; Gómez \& Duart, 2012; Güzera \& Canera, 2014; Bonk \& Graham, 2006). The advantages that this teaching method offers are multifold. How do students perceive the hybrid learning? How are the components of the hybrid learning valued? Are there differences in the perceptions of students for the hybrid learning based 
on learning styles? What is the learning style of students? All these questions will be answered in this study. The purpose of the paper is to study the perception of the hybrid learning and the learning styles of students. Another objective is the analysis of the perception of the hybrid learning in accordance to the learning style. The study of instruction styles are a new field of research, which is fundamentally important to both students and universities.

\section{Literature Review}

The hybrid learning has a number of advantages for both students and professors. It has a positive impact on students' academic achievement, student satisfaction, makes for efficient use of resources, increases students' communication abilities. Studies have concluded that it has a positive impact on students' academic performance (Boyle, Bradley, Chalk, Jones, \& Pickard, 2003; Dziuban, Graham, \& Picciano, 2014; Dziuban, Moskal, \& Hartman, 2004; Garnham \& Kaleta, 2002; Lim \& Morris, 2009; O'Toole \& Absalom, 2003; López-Pérez, Pérez-López, \& Rodríguez-Ariza, 2011). Promsurin and Vitayapirak (2015) reached to the conclusion that the hybrid learning has a positive impact on both academic results and student satisfaction. Blankson and Kyei-Blankson (2008) obtained the same conclusion. Multiple empirical studies conclude that hybrid courses are the most effective (Means, Toyama, Murphy, Bakia, \& Jones, 2010; Ajide \& Tik, 2009; Atiyah, El Sherbiny, \& Guirguis, 2015). Several researchers believe that the hybrid learning will be the most utilized method in universities (Norberg, Dziuban, \& Moskal, 2011; Bonk \& Graham, 2006). It assists students in integrating their existing and new knowledge. In this manner the student selfmanages the study program (Osguthorpe \& Graham, 2003). Similarly, the student decides the study time (Garnham \& Kaleta, 2002; Smyth, Houghton, Cooney, \& Casey, 2012; Gómez \& Duart, 2012; Mitchell \& Honore, 2007). Studies show that students who pursue courses through the hybrid learning are better motivated and pay more attention during the study process (Sharpe, Benfield, Roberts, \& Francis, 2006; Woltering, Herrler, Spitzer, \& Spreckelsen, 2009; Donnelly, 2010; Wang, Shen, Novak, \& Pan, 2009; Martinez-Caro \& Campuzano-Bolarin, 2011). Professors argue that hybrid courses develop critical thinking skills in students. This teaching method also has an impact on the quality of instruction (Garrison \& Vaughan, 2008; Ajide \& Tik, 2009; Glazer, 2011; Owston, York, \& Murtha, 2013; Owston, Wideman, Murphy, \& Lupshenyuk, 2008; Thorne, 2003).

Students have their own way of studying. The manner in which they study is called a learning style (Ford \& Chen, 2000). Everyone learns through different methods, as a result there exist different learning styles. Certain researchers have studied the impact that gender has on learning styles (Bidabadi \& Yamat, 2010; Wehrwein, Lujan, \& DiCarlo, 2007). Bidabadi and Yamat (2010) concluded that gender does not have an impact on learning style preferences. Conversely, Wehrwein, Lujan and DiCarlo (2007) concluded that gender impacts learning styles.

This research study will employ VAK (Fleming, 1995) in order to determine learning styles, which include the visual, aural and kinesthetic learning styles. Students who use the visual learning style prefer to learn through images, pictures, diagrams, and films. They have a preference for diagramatic and schematic displays. Whereas, students who use the aural learning style prefer receiving information through listening and discussing. Such students best learn by remembering what they have heard. Last, students who learn through the kinesthetic learning style prefer handson experiences through tactile exploration, by touching, experimenting and doing. These students tend to pursue their perceptions rather than instructions. Identifying the student's learning style assists professors in developing a compatible learning process. Its impact is direct on student engagement and outcomes (Bostrom \& Lassen, 2006). The conclusions of research on a correlation between learning styles and the perception of teaching methods are contradictory. Some argue that there exists a strong correlation between the two (Graff, 2003; Dobson, 2010), while others argue that there does not exist a correlation between them (Shaw \& Marlow, 1999; Yari, 2012; Torre, 2013).

The research questions are:

1. Which is the students' learning style?

2. What is student perception of the hybrid learning?

3. Does study style impact student perception of the hybrid learning? 
The research hypotheses are:

* H1a: Students with different learning styles have the same perception of the hybrid learning $(\alpha=0.05)$.

* H1b: Students with different learning styles value the same the components of the hybrid learning $(\alpha=0.05)$.

* H2: Gender does not have an impact on learning style $(\alpha=0.05)$.

* H3: Students from different study areas have the same learning style preference $(\alpha=0.05)$.

* H4: Male and female students have the same perception of the hybrid learning $(\alpha=0.05)$.

* H5: Students from different study areas have the same perception of the hybrid learning $(\alpha=0.05)$.

* H6: Students with different academic results have the same perception of the hybrid learning $(\alpha=0.05)$.

The conceptual model used in this study is as follows:

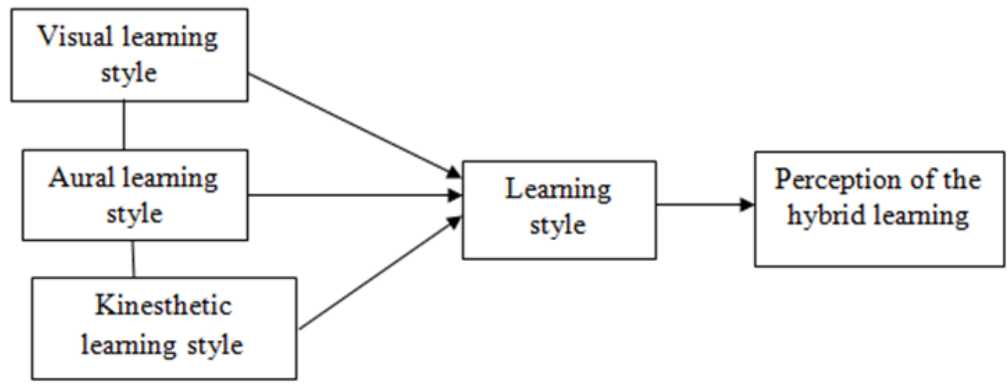

\section{Methodology}

The method used is descriptive and comparative analysis. The research instrument is the questionnaire (Fleming, 1995). The questionnaire considers two dimensions: student learning style and the perception of the hybrid learning. The first part consists of questions with alternatives, whereas, the second part contains a 5-point Likert scale survey, ranging from "Strongly Agree" to "Strongly Disagree". The questionnaires were distributed online during the second semester of the 2016-2017 academic year. The participants are 89 Albanian university students. Fully completed questionnaires are 82 . The response return rate is $92.1 \%$. The descriptive data of the sample study is displayed below.
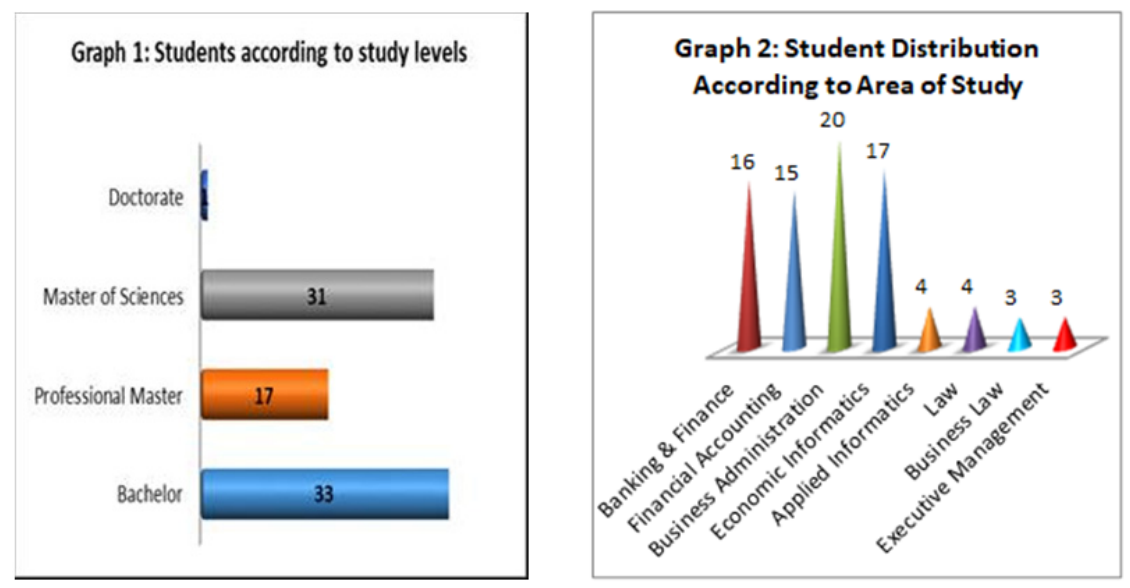


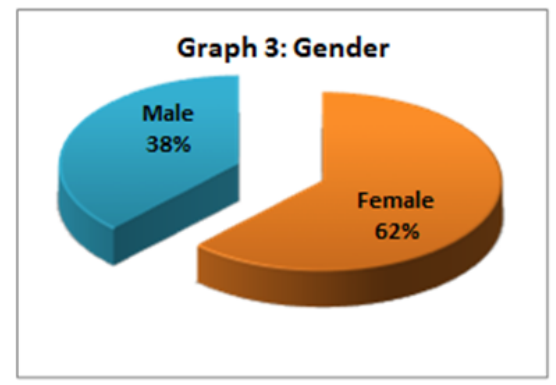

Graph 5: Employment status

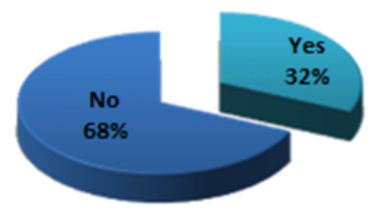

Graph 4: Grade Average

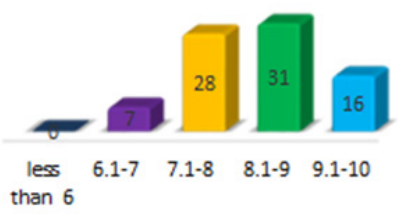

Graph 6: Age

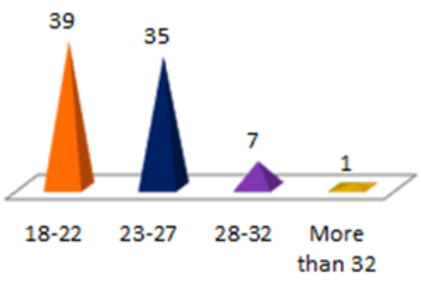

SPSS 20 and JASP-0.8.1.2 were utilized for data analysis. Cronbach' a coefficient for the questionnaire is 0.758 (Table 1). The data of the study are valid for analytical purposes. Table 2 provides the reliability coefficients for each variable.

Table 1: Cronbach's a coefficient of the questionnaire

\begin{tabular}{cc}
\hline & Cronbach's $\alpha$ \\
\hline scale & 0.758 \\
\hline Note. Scale consists of items perception of the hybrid learning, learning style
\end{tabular}

Table 2: Cronbach's $\alpha$ coefficient of variables

\begin{tabular}{lc}
\hline & If item dropped \\
\cline { 2 - 2 } Perception of the hybrid learning & Cronbach's $\boldsymbol{\alpha}$ \\
\hline Learning style & 0.757 \\
\hline
\end{tabular}

\section{Empirical analysis}

The perception of the hybrid learning has the highest mean $=3.805$. The standard deviation is low, for the learning style 0.8084 and the perception of the hybrid learning 0.5760 . Between the values there do not exist great differences, thus the data are distributed around the mean value.

Table 3: Descriptive statistics of the variables

\begin{tabular}{lcc}
\hline & Learning style & Perception of the hybrid learning \\
\hline Valid & 82 & 82 \\
Missing & 0 & 0 \\
Mean & 1.841 & $\mathbf{3 . 8 0 5}$ \\
Std. Deviation & 0.8084 & $\mathbf{0 . 5 7 6 0}$ \\
Minimum & 1.000 & 2.000 \\
Maximum & 3.000 & 5.000 \\
\hline
\end{tabular}


Which is the students' learning style?

The largest part of the surveyed students belong to the visual learning style. Of 82 students, 34 prefer studying through the visual learning style, 27 students choose the aural learning style and 21 prefer the kinesthetic learning style to study. All three styles are utilized by students. A similar distribution occurs when studying male and female preferences. Table 5 shows detailed preferences of learning style in accordance with gender. Graphs 7 and 8 are diagrammatic representations of the preferences.

Table 4: Learning style

\begin{tabular}{lcccc}
\hline & Frequency & Percent & Valid Percent & Cumulative Percent \\
\hline Visual learning style & 34 & 41.5 & 41.5 & 41.5 \\
Aural learning style & 27 & 32.9 & 32.9 & 74.4 \\
Kinesthetic learning style & 21 & 25.6 & 25.6 & 100.0 \\
Total & 82 & 100.0 & 100.0 & \\
\hline
\end{tabular}

Table 5: Learning style and gender

\begin{tabular}{lccc}
\hline & Gender: & & \\
\hline Learning style & Female & Male & Total \\
Visual learning style & 21 & 13 & 34 \\
Aural learning style & 17 & 10 & 27 \\
Kinesthetic learning style & 13 & 8 & 21 \\
Total & 51 & 31 & 82 \\
\hline
\end{tabular}
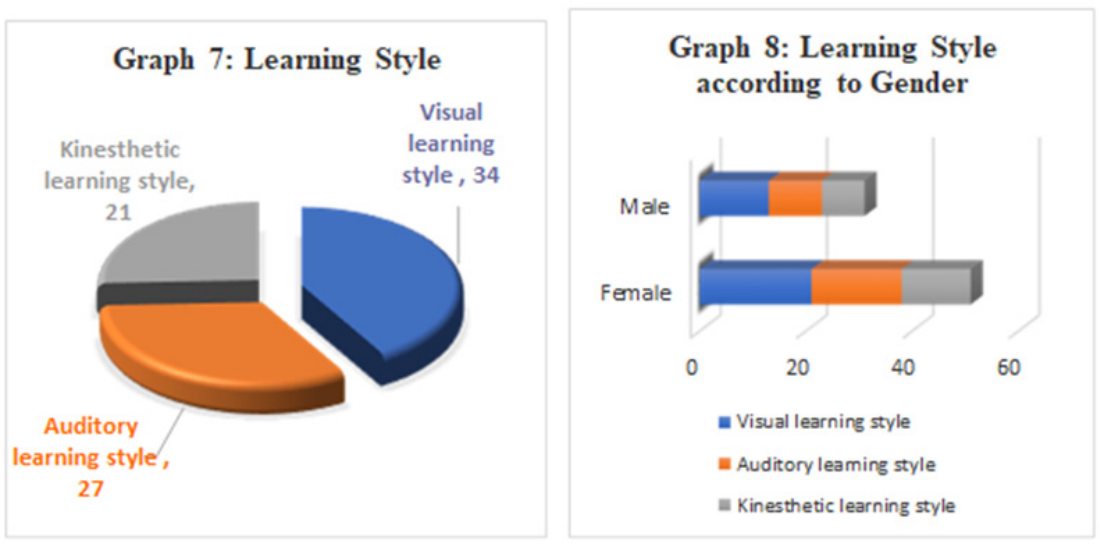

What is student perception of the hybrid learning?

Student evaluation of the hybrid learning is positive. User-friendliness has the highest valuation of the components of the hybrid learning with mean value 3.854 . Second place, general output, mean value 3.732. Third place, course quality, mean value 3.707. Last, purpose of use, mean value 3.646. Student evaluation for hybrid learning is 3.805 .

Tabela 6: Hybrid Learning

\begin{tabular}{lcccc}
\hline & N & Mean & SD & SE \\
\hline User-friendliness & 82.00 & $\mathbf{3 . 8 5 4}$ & 0.669 & 0.074 \\
Course quality & 82.00 & 3.707 & 0.598 & 0.066 \\
Purpose of use & 82.00 & 3.646 & 0.655 & 0.072 \\
General output & 82.00 & 3.732 & 0.754 & 0.083 \\
Perception of the hybrid learning & 82.00 & 3.805 & 0.576 & 0.064 \\
\hline
\end{tabular}


Does learning style impact student perception of the hybrid learning?

Table 7 shows that Pearson correlation coefficient is 0.092 and $p=0.412$. Thus, between learning style and the perception of the hybrid learning there does not exist a significant statistical correlation. Between the two variables there exists a weak positive insignificant correlation. From the analysis it is concluded that learning style does not have an impact on student perception of the hybrid learning.

Table 7: Pearson Correlations

\begin{tabular}{llcc}
\hline & & Learning style & Perception of the hybrid learning \\
\hline \multirow{4}{*}{ Learning style } & Pearson's r & - & 0.092 \\
& p-value & - & 0.412 \\
& Upper 95\% Cl & - & 0.303 \\
& Lower 95\% Cl & - & -0.128 \\
& Pearson's r & - & - \\
Perception of the hybrid learning & p-value & - \\
& Upper 95\% Cl & - \\
& Lower 95\% Cl & & \\
\hline
\end{tabular}

${ }^{*} p<.05,{ }^{* *} p<.01,{ }^{* * *} p<.001$

H1a: Students with different learning styles have the same perception of the hybrid learning $(\alpha=0.05)$.

Table 8 values demonstrate Sig .660 (Table 8). As a result, there do not exist significant differences, therefore students with different learning styles have the same perception of the hybrid learning. Mean valuations of the hybrid learning have insignificant differences between them (Table 9). However, students who study through the kinesthetic learning style have the highest valuation. Analysis shows that students have the same perception of the hybrid learning, thus hypothesis $\mathrm{H} 1 \mathrm{a}$ is supported with confidence interval $95 \%$.

Table 8: One - Way ANOVA

\begin{tabular}{lccccc}
\hline & Sum of Squares & df & Mean Square & F & Sig. \\
\hline Between Groups & .282 & 2 & .141 & .418 & .660 \\
Within Groups & 26.596 & 79 & .337 & & \\
Total & 26.878 & 81 & & & \\
\hline
\end{tabular}

Table 9: Descriptive data of learning styles

\begin{tabular}{|c|c|c|c|c|c|c|c|c|}
\hline & $\mathrm{N}$ & Mean & Deviation & Std. & $\begin{array}{r}\text { 95\% Confider } \\
\text { ( }\end{array}$ & $\begin{array}{l}\text { ce Interval for } \\
\text { an }\end{array}$ & Minimum & aximum \\
\hline & & & & & Lower Bound & Upper Bound & & \\
\hline Visual learning style & 34 & 3.74 & .511 & .088 & 3.56 & 3.91 & 2 & 4 \\
\hline Aural learning style & 27 & 3.85 & .662 & 127 & 3.59 & 4.11 & 2 & 5 \\
\hline Kinesthetic learning style & 21 & 3.86 & .573 & 125 & 3.60 & 4.12 & 3 & 5 \\
\hline Total & 82 & 3.80 & .576 & .064 & 3.68 & 3.93 & 2 & 5 \\
\hline
\end{tabular}

H1b: Students with different learning styles value the same the components of the hybrid learning $(\alpha=0.05)$.

Students applying the visual, aural and kinesthetic learning styles have the same valuation of the hybrid learning. There do not exist significant statistical differences between them. The perception of the components of the hybrid learning is the same between students, thus hypothesis $\mathrm{H} 1 \mathrm{~b}$ is supported with confidence interval $95 \%$. Values are displayed in detail on Table 10: OneWay Anova. 
Table 10: One - Way ANOVA

\begin{tabular}{|c|c|c|c|c|c|c|}
\hline & & Sum of Squares & $\mathrm{df}$ & Mean Square & $F$ & Sig. \\
\hline & Between Groups & .209 & 2 & .104 & .229 & .796 \\
\hline \multirow[t]{3}{*}{ User-friendliness } & Within Groups & 36.035 & 79 & .456 & & \\
\hline & Total & 36.244 & 81 & & & \\
\hline & Between Groups & 1.914 & 2 & .957 & 2.302 & 107 \\
\hline \multirow[t]{3}{*}{ Purpose of use } & Within Groups & 32.830 & 79 & .416 & & \\
\hline & Total & 34.744 & 81 & & & \\
\hline & Between Groups & .095 & 2 & .048 & .130 & .878 \\
\hline \multirow[t]{3}{*}{ Course quality } & Within Groups & 28.880 & 79 & .366 & & \\
\hline & Total & 28.976 & 81 & & & \\
\hline & Between Groups & .582 & 2 & .291 & .505 & .605 \\
\hline \multirow[t]{2}{*}{ General output } & Within Groups & 45.515 & 79 & .576 & & \\
\hline & Total & 46.098 & 81 & & & \\
\hline
\end{tabular}

H2: Gender does not have an impact on learning style $(\alpha=0.05)$.

In order to prove hypothesis H2, Table 11 is used: Independent Samples T-Test. Value of $p$ is greater than 0.05 . Gender does not have an impact of learning style. Female students have the same preferences as male students. Hypothesis $\mathrm{H} 2$ is supported with confidence interval $95 \%$. Table 12 provides descriptive statistics on gender. Graph 9 is a representation of Bayesian analysis which supports diagrammatically hypothesis $\mathrm{H} 2$ (graph $\mathrm{H}_{0}$ ).

Table 11: Independent Samples T-Test

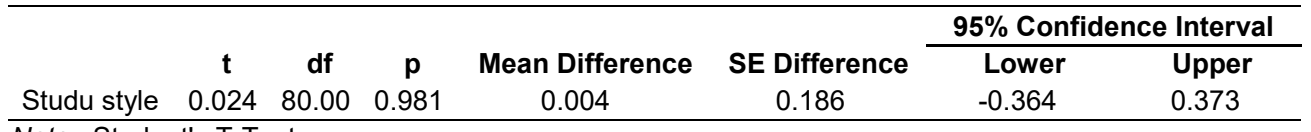

Note. Student's T-Test.

Table 12: Descriptive data of gender

\begin{tabular}{lccccc} 
& Group & N & Mean & SD & SE \\
\hline Study style & Female & 51 & 1.843 & 0.809 & 0.113 \\
& Male & 31 & 1.839 & 0.820 & 0.147 \\
\hline
\end{tabular}
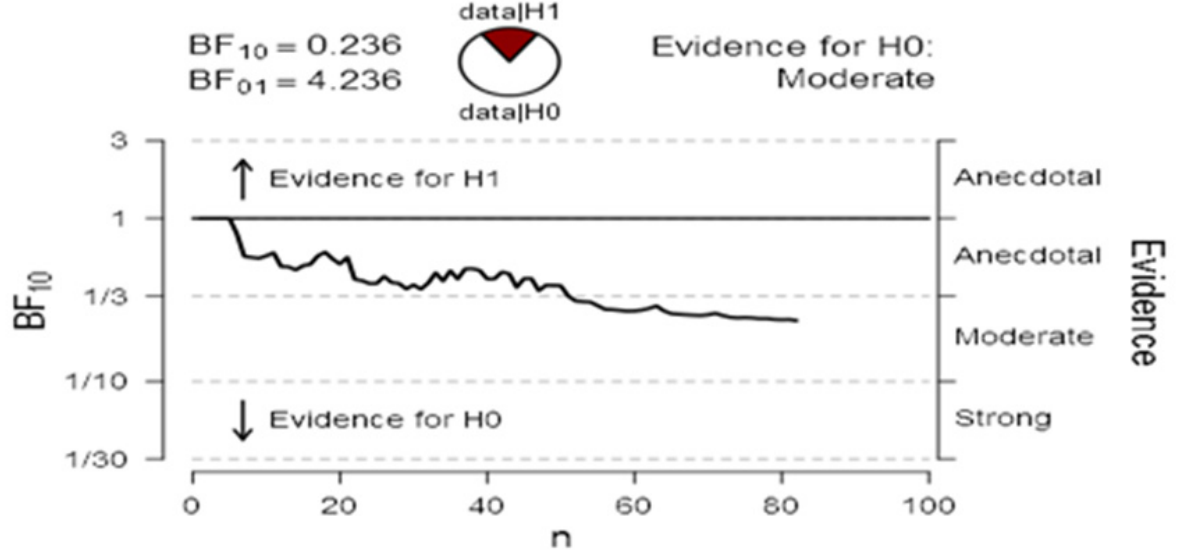

Graph 9: Gender and learning style 
H3: Students from different study areas have the same learning style preference $(\alpha=0.05)$.

Area of study does not have an impact on learning style. Every student has their way of studying regardless of the study program. Students from different areas of study prefer similar learning styles. Sig value .805 (Table 13), which supports hypothesis H3 with confidence interval $95 \%$. Graph 10 shows preferences for learning styles in accordance with study area.

Table 13: One - Way ANOVA

\begin{tabular}{lccccc}
\hline & Sum of Squares & $\mathrm{df}$ & Mean Square & $\mathrm{F}$ & Sig. \\
\hline Between Groups & 2.552 & 7 & .365 & .535 & .805 \\
Within Groups & 50.387 & 74 & .681 & & \\
Total & 52.939 & 81 & & & \\
\hline
\end{tabular}

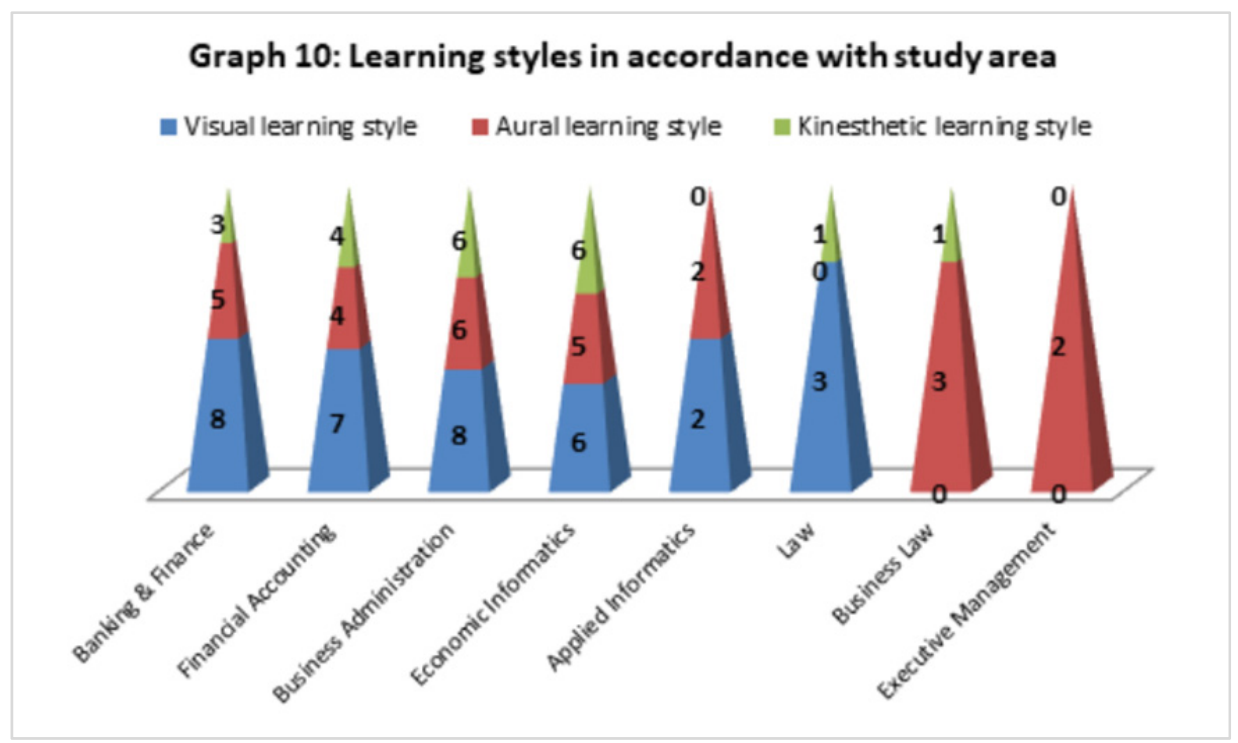

H4: Male and female students have the same perception of the hybrid learning $(\alpha=0.05)$.

Table 14 shows values of $p$ are greater than $\alpha=0.05$. The perception of the hybrid learning and the components of the hybrid learning is the same for male and female students. Between them there do not exist significant differences. Hypothesis $\mathrm{H} 4$ is supported with confidence interval $95 \%$. Mean value for males is highest for the three components of the hybrid learning (userfriendliness, course quality, general output) and the perception of the hybrid learning. Female students have the highest mean value for purpose of use (Table 15).

Table 14: Independent Samples T-Test

\begin{tabular}{lccccc}
\hline & $\mathbf{t}$ & $\mathbf{d f}$ & $\mathbf{p}$ & Mean Difference & SE Difference \\
\hline User-friendliness & -0.182 & 80.00 & 0.856 & -0.028 & 0.144 \\
Course quality & -1.173 & 80.00 & 0.244 & -0.159 & 0.136 \\
Purpose of use & 0.359 & 80.00 & 0.721 & 0.054 & 0.146 \\
General output & -0.095 & 80.00 & 0.924 & -0.016 & 0.162 \\
Perception of the hybrid learning & -1.209 & 80.00 & 0.230 & -0.158 & 0.128 \\
\hline
\end{tabular}

Note. Student's T-Test. 
Table 15: Descriptive statistics

\begin{tabular}{lccccc}
\hline & Group & $\mathbf{N}$ & Mean & SD & SE \\
\hline User-friendliness & Female & 51 & 3.843 & 0.731 & 0.102 \\
& Male & 31 & 3.871 & 0.562 & 0.101 \\
Course quality & Female & 51 & 3.647 & 0.594 & 0.083 \\
& Male & 31 & 3.806 & 0.601 & 0.108 \\
Purpose of use & Female & 51 & 3.667 & 0.683 & 0.096 \\
& Male & 31 & 3.613 & 0.615 & 0.110 \\
General output & Female & 51 & 3.725 & 0.827 & 0.116 \\
& Male & 31 & 3.742 & 0.631 & 0.113 \\
Perception of the hybrid learning & Female & 51 & 3.745 & 0.595 & 0.083 \\
& Male & 31 & 3.903 & 0.539 & 0.097 \\
\hline
\end{tabular}

H5: Students from different study areas have the same perception of the hybrid learning $(\alpha=0.05)$.

Perception of the hybrid learning is the same. However, valuations of its components are not the same. Students of different study areas rate the purpose of use in the hybrid learning differently. For the three other components there do not exist significant differences. Nevertheless, Sig $=0.005$ for one component rejects hypothesis H5. Graphs below show the Bayesian analysis of each correlation.

Table 16: One - Way ANOVA

\begin{tabular}{|c|c|c|c|c|c|c|}
\hline & & Sum of Squares & df & Mean Square & $\mathrm{F}$ & Sig. \\
\hline & Between Groups & 1.893 & 7 & .270 & .801 & .589 \\
\hline \multirow[t]{3}{*}{ Perception of hybrid learning } & Within Groups & 24.986 & 74 & .338 & & \\
\hline & Total & 26.878 & 81 & & & \\
\hline & Between Groups & 2.461 & 7 & .352 & .770 & .614 \\
\hline \multirow[t]{3}{*}{ User-friendliness } & Within Groups & 33.783 & 74 & .457 & & \\
\hline & Total & 36.244 & 81 & & & \\
\hline & Between Groups & 8.079 & 7 & 1.154 & 3.203 & .005 \\
\hline \multirow[t]{3}{*}{ Purpose of use } & Within Groups & 26.665 & 74 & .360 & & \\
\hline & Total & 34.744 & 81 & & & \\
\hline & Between Groups & 3.075 & 7 & .439 & 1.255 & .284 \\
\hline \multirow[t]{3}{*}{ Course quality } & Within Groups & 25.900 & 74 & .350 & & \\
\hline & Total & 28.976 & 81 & & & \\
\hline & Between Groups & 5.894 & 7 & .842 & 1.550 & .164 \\
\hline \multirow[t]{2}{*}{ General output } & Within Groups & 40.204 & 74 & .543 & & \\
\hline & Total & 46.098 & 81 & & & \\
\hline
\end{tabular}

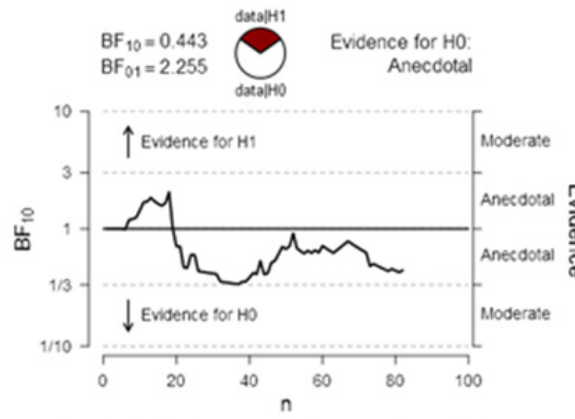

Graph 11: Study area and perception of the hybrid leaming

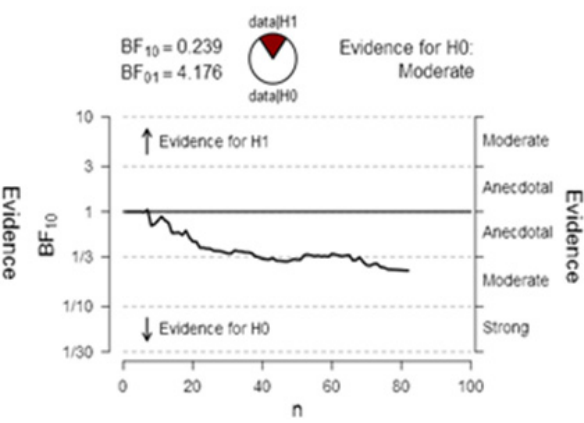

Graph 12: Study area and user-friendliness 


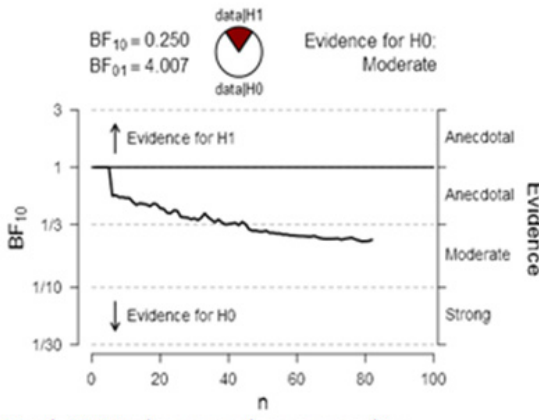

Graph 13: Study area and course quality

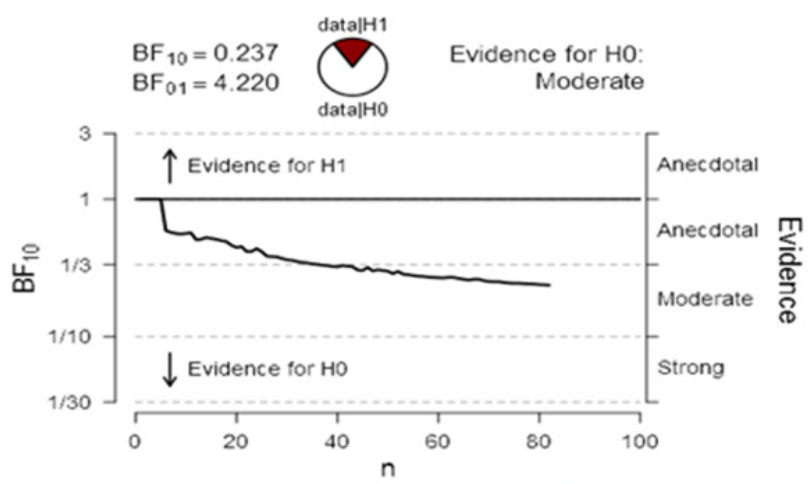

Graph 15: Study area and general output

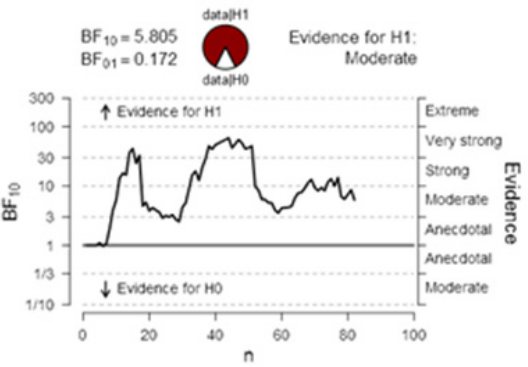

Graph 14: Study area and purpose of use

H6: Students with different academic achievement have the same perception of the hybrid learning $(\alpha=0.05)$.

Table 17 data shows that students with differing academic performance have the same perception of the hybrid learning. Students have a positive perception of the hybrid learning. Analysis shows that hypothesis $\mathrm{H} 6$ is supported with confidence interval $95 \%$.

Table 17: One - Way ANOVA

\begin{tabular}{|c|c|c|c|c|c|c|}
\hline & & Sum of Squares & df & Mean Square & $\mathrm{F}$ & Sig. \\
\hline & Between Groups & 2.093 & 3 & .698 & 2.195 & .095 \\
\hline \multirow[t]{3}{*}{ Perception of the hybrid learning } & Within Groups & 24.785 & 78 & .318 & & \\
\hline & Total & 26.878 & 81 & & & \\
\hline & Between Groups & 3.201 & 3 & 1.067 & 2.519 & .064 \\
\hline \multirow[t]{3}{*}{ User-friendliness } & Within Groups & 33.043 & 78 & .424 & & \\
\hline & Total & 36.244 & 81 & & & \\
\hline & Between Groups & 1.201 & 3 & .400 & .931 & .430 \\
\hline \multirow[t]{3}{*}{ Purpose of use } & Within Groups & 33.543 & 78 & .430 & & \\
\hline & Total & 34.744 & 81 & & & \\
\hline & Between Groups & .593 & 3 & .198 & .543 & .654 \\
\hline \multirow[t]{3}{*}{ Course quality } & Within Groups & 28.382 & 78 & .364 & & \\
\hline & Total & 28.976 & 81 & & & \\
\hline & Between Groups & 2.038 & 3 & .679 & 1.202 & .314 \\
\hline \multirow[t]{2}{*}{ General output } & Within Groups & 44.060 & 78 & .565 & & \\
\hline & Total & 46.098 & 81 & & & \\
\hline
\end{tabular}




\section{Conclusions and Recommendations}

Students are users of all three learning styles, although the visual learning style is best liked. Generally, students evaluate positively the hybrid learning. Students who belong to the kinesthetic learning style, value the most the hybrid learning. Students' gender does not have an impact on learning style and perception of the hybrid learning. The conclusions of the study are in line with the literature review.

There exist significant statistical differences between students of different study areas and the component of the hybrid learning, the purpose of use. The motivation for taking hybrid courses differs from one study area to another. Students are generally satisfied with hybrid courses and therefore recommend them to their friends. Universities need to conduct further research on learning styles in order to select the most compatible teaching methods. Based on the study's conclusions, it is recommended the creation of hybrid courses in the future.

\section{References}

Ajide, O. E., \& Tik, C. C. (2009). A study on the effectiveness of blended learning. 2nd International Conference of Teaching and Learning (pp. 1-7). Malaysia: INTI University College.

Atiyah, J. M., El Sherbiny, M. M., \& Guirguis, S. K. (2015). Evaluation of E-Learning Program versus Traditional Education Instruction for Undergraduate. International Journal of Advanced Research in Science, Engineering and Technology , 2 (7), 776-786.

Bidabadi, F. S., \& Yamat, H. (2010). Learning style preferences by Iranian EFL freshman university students. Procedia - Social and Behavioral Sciences , 7, 219-226.

Blankson, J., \& Kyei-Blankson, L. (2008). Nontraditional Students' Perception of a Blended Course: Integrating Synchronous Online Discussion and Face-to-Face Instruction. Journal of Interactive Learning Research , 3 (19), 421-438.

Bonk, C. J., \& Graham, C. R. (2006). The Handbook of Blended Learning: Global Perspectives, Local Designs. San Francisco: Pfeiffer Publishing.

Bostrom, L., \& Lassen, L. M. (2006). Unraveling learning, learning styles, learning strategies and metacognition. Education \& Training , 48, 178-189.

Boyle, T., Bradley, C., Chalk, P., Jones, R., \& Pickard, P. (2003). Using blended learning to improve student suçess rates in learning to program. Journal of Educational Media , 28 (2-3), 165-178.

Collopy, R. M., \& Arnold, J. M. (2009). To blend or not to blend: Online and blended learning environments in undergraduate teacher education. Issues in Teacher Education , 18 (2), 85-101.

Dobson, J. (2010). A comparison between learning style preferences and sex, status, and course performance. Advances in Physiology Education , 34 (4), 197-204.

Donnelly, R. (2010). Harmonizing technology with interaction in blended problem-based learning. Computers \& Education , 54 (2), 350-359.

Dziuban, C. D., Moskal, P., \& Hartman, J. (2004). Blended Learning. Colorado: Research Bulletin of Educause Center for Applied Research.

Dziuban, C., Graham, C., \& Piçiano, A. (2014). Blended learning: Research perspectives. New York: Routledge.

Fleming, N. (1995). I'm different; not dumb. Modes of presentation (VARK) in the tertiary classroom. Proceedings of the 1995 Annual Conference of the Higher Education and Research Development Society of Australasia (pp. 308-313). Queensland: HERDSA.

Ford, N., \& Chen, S. (2000). Individual differences, hypermedia, navigation, and learning: An empirical study. Journal of Educational Multimedia and Hypermedia , 9, 281-311.

Garnham, C., \& Kaleta, R. (2002). Introduction to hybrid courses. Teaching with Technology Today , 8 (6), 1-6.

Garrison, D. R., \& Vaughan, N. D. (2008). Blended learning in higher education: Framework, principles, and guidelines. San Francisco: Jossey-Bass.

Glazer, F. S. (2011). Blended Learning: Across the Disciplines, Across the Academy (New Pedagogies and Practices for Teaching in Higher Education). Virginia: Stylus Publishing.

Gómez, L., \& Duart, J. (2012). A hybrid approach to university subject learning activities. British Journal of Educational Technology , 43 (2), 259-271.

Graff, M. G. (2003). Cognitive Style and attitudes towards using online learning and assessment methods. The Electronic Journal of E-learning , 1 (1), 21-28.

Güzera, B., \& Canera, H. (2014). The past, present and future of blended learning: an in depth analysis of literature. Social and Behavioral Sciences , 4596 - 4603.

Lim, D. H., \& Morris, M. L. (2009). Learner and instructional factors influencing learning outcomes within a blended learning environment. Educational Technology \& Society , 12 (4), 282-293. 
López-Pérez, M. V., Pérez-López, M. C., \& Rodríguez-Ariza, L. (2011). Blended learning in higher education: Students' perceptions and their relation to outcomes. Computers \& Education , 56 (3), 818-826.

Martinez-Caro, E., \& Campuzano-Bolarin, F. (2011). Factors affecting students' satisfaction in engineering disciplines: Traditional vs. blended approaches. European Journal of Engineering Education , 36 (5), 473483.

Means, B., Toyama, Y., Murphy, R., Bakia, M., \& Jones, K. (2010). Evaluation of evidence-based practices in online learning: A meta-analysis and review of online learning studies. Washington, DC: U.S. Department of Education.

Mitchell, A., \& Honore, S. (2007). Criteria for suçessful blended learning. Industrial and Commercial Training , 39 (3), 143-149.

Norberg, A., Dziuban, C. D., \& Moskal, P. D. (2011). A time-based blended learning model. On the Horizon , 19 , 207-216.

Osguthorpe, T. R., \& Graham, C. R. (2003). Blended learning environments: Definitions and directions. Quarterly Review of Distance Education , 4 (3), 227-233.

O'Toole, J. M., \& Absalom, D. J. (2003). The impact of blended learning on student outcomes: Is there room on the horse for two. Journal of Educational Media , 28 (2-3), 179-190.

Owston, R., Wideman, H., Murphy, J., \& Lupshenyuk, D. (2008). Blended teacher professional development: A synthesis of three program evaluations. The Internet and Higher Education , 11 (3-4), 201-210.

Owston, R., York, D., \& Murtha, S. (2013). Student perceptions and achievement in a university blended learning strategic initiative. The Internet and Higher Education, 18, 38-46.

Promsurin, S., \& Vitayapirak, J. (2015). Comparison of e-Learning, Blended and Traditional English Teaching Methods: A Case Study of Ban Hong Community Education College. International Journal of Languages, Literature and Linguistics, 1 (2), 80-86.

Sharpe, R., Benfield, G., Roberts, G., \& Francis, R. (2006). The undergraduate experience of blended elearning: A review of UK literature and practice. York: The Higher Education Academy.

Shaw, G., \& Marlow, N. (1999). The role of student learning styles, gender, attitudes and perceptions on information and communication technology assisted learning. Computers \& Education , 33 (4), 223 - 234.

Smyth, S., Houghton, C., Cooney, A., \& Casey, D. (2012). Students' experiences of blended learning across a range of postgraduate programmes. Nurse Education Today, 32, 464-468.

Thorne, K. (2003). Blended learning: how to integrate online and traditional learning. London: Kogan page.

Torre, J. M. (2013). Variances on Students' Blended Learning Perception Açording. Journal of Education and Practice , 4 (20), 160-167.

Wang, M., Shen, R., Novak, D., \& Pan, X. (2009). The impact of mobile learning on students' learning behaviours and performance: Report from a large blended classroom. British Journal of Educational Technology , 40 (4), 673-695.

Wehrwein, E. A., Lujan, H. L., \& DiCarlo, S. (2007). Gender differences in learning style preferences among undergraduate physiology students. American Journal of Physiology - Advances in Physiology Education , 31 (2), 153-157.

Woltering, V., Herrler, A., Spitzer, K., \& Spreckelsen, C. (2009). Blended learning positively affects students' satisfaction and the role of the tutor in the problem-based learning process: Results of a mixed-method evaluation. Advances in Health Science Education, 14, 725-738.

Yari, T. (2012). Exploring the relationship between various learning preferences and final results achieved by Iranian EFL learners: A case study. Advances in Asian Social Science , 2 (3), 526-531. 